\title{
A METHOD TO ASSESS THE IMPACT OF HIGH TIDES, STORMS AND STORM SURGES AS VTTAL ELEMENTS IN CLMATIC HISTORY THE CASE OF STORMY WEATHER AND DIKES IN THE NORTHERN PART OF FLANDERS, 1488 TO 1609
}

\author{
A.M.J. DE KRAKER \\ Department of Human Geography, University of Amsterdam, \\ Nieuwe Prinsengracht 130, \\ $1018 \mathrm{VZ}$, Amsterdam, \\ The Netherlands
}

\begin{abstract}
In this paper a new method is introduced to assess the impact of storminess during the preinstrumental period. The method is based on written sources. For this purpose Flemish documentary sources are taken as an example originating from a polder region between Ghent and Antwerp dating from the period 1488 to 1609 . These documentary sources are continuous and homogeneous. The polders were protected by dikes, which had had to be maintained regularly. The ammal upkeep was answered for in the annual dikes accounts in which nearly each storm that caused damage to the dikes was recorded. In order to assess the impact of storminess, these storms have been categorised, based on the following three principles: (a) the exact wording in the text, (b) the circumstances in which a storm appeared, (c) the consoquences to which a storm has led, e.g. mumber of acres flooded. Accordingly eight separate categories are distinguished with storms ranging from one point to eight points. So in the first category the least important storms are given only one point. In category eight the storm surges appear, that have led to the flooding of large areas. These storns are given eight points. As the method enables us to assess the impact of storminess throughout the period, it shows only a smatl increase of storminess during the first quarter of the sixteenth century and a large increase in storminess during the second half of that century. Finally, looking at the stom pattern at Flushing between 1848 and 1990 , there also appears to be a relative strong increase in storminess beginning around the 1950 s. Whereas such a similarity in increase in storminess between these two quite different periods can hardly be coincidental, there must be some common cause. Could it be that periods of a relative strong increase of storminess precede periods of climatic change?
\end{abstract}

\section{Introduction}

Documentary sources about storms and their consequences are hardly ever uniform and continuous. Therefore, it is very difficult to use such data to assess the impact of storms as vital elements of climatic history. Perhaps that is why earlier attempts by Easton (1928) and Gottschalk (1971, 1975, 1977) to propose some kind of method have not met with great enthusiasm (Alexandre, 1987). Nevertheless, documentary sources (Ingram, et al., 1981; Lamb, 1991) mostly provide the only rich collection of proxy data for the understanding of climatic history as early as the seventeenth century. So, in this paper, thanks to a large number of documentary sources, a method is proposed to measure the impact of storms as vital elements of climatic history in coastal lands. 
The tormented history of Flanders provides us with a rich store of written sources reaching as far back as the High Middle Ages. These sources contain a great deal of climatic data. Bradley (1994) suggested that enough data is available to enable us to reconstruct local climatic variations in the area of the North Sea. I think this might just as well be Flanders (Augustyn, 1992), because very special documentary sources might just make it possible to reconstruct the impact of some specific elements of the climatic history of this region. The kind of documentary sources in question deal with the upkeep and repair of the dikes, which were especially vulnerable to all kinds of high tides, storms and storm surges.

In order to develop a method, I have studied the written sources of the coastal area of the Vier Ambachten and the Land van Saeftinghe from 1488 to 1609 . I think this Flemish coastal region is large enough and most vulnerable to storms. The period from 1488 to 1609 is a very tormented period that witnessed several wars and experienced some important changes. The beginming of the period in question is marked by the large scale inundation in the western part of the area. The end of the period is marked by the beginning of the Twelve Years Truce (1609-1621).

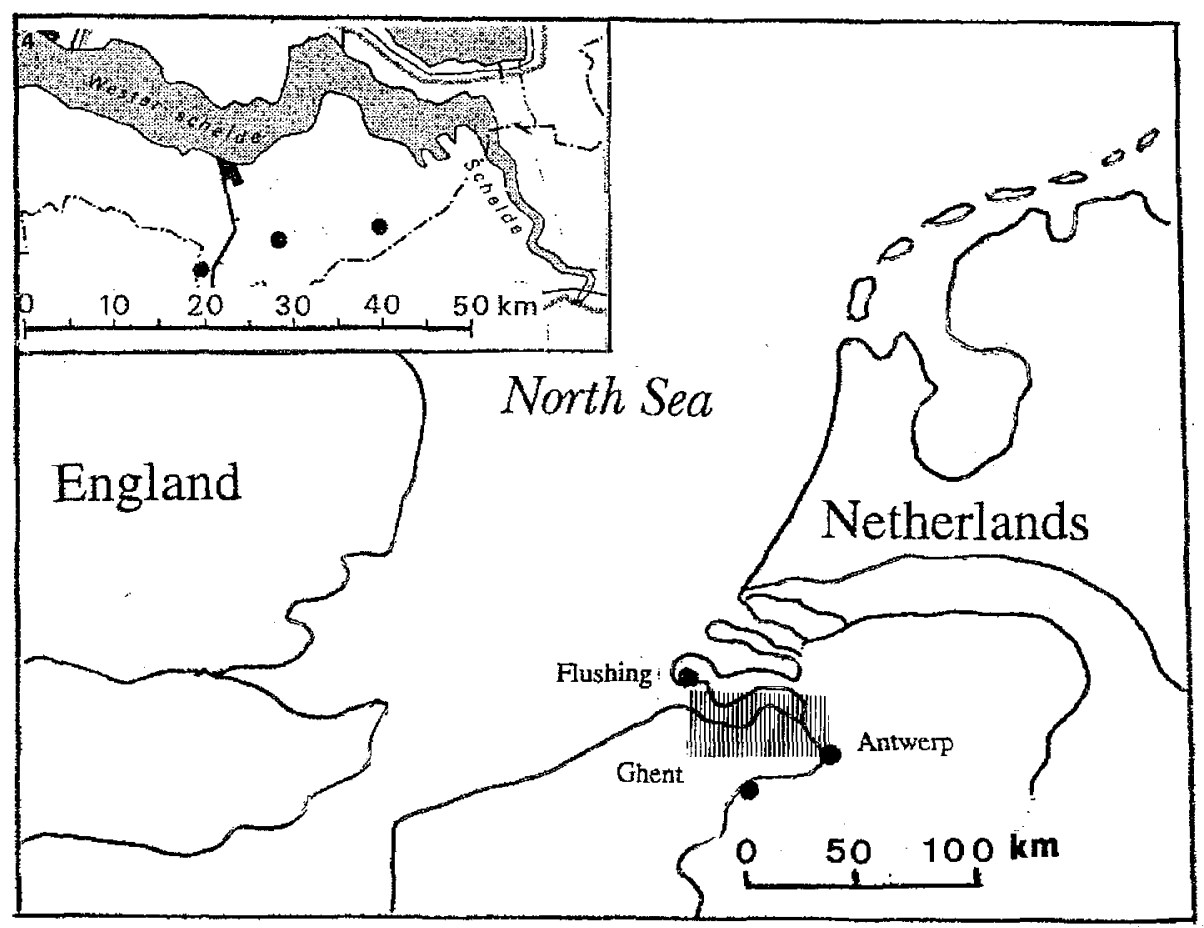

Figure 1. The coastal region of the ancient Vier Ambachten and the Land of Saefinghe, now ZeenwsVlaanderen, as part of the North Sea region, present situation. 


\section{Assessing the impact of storms}

\subsection{EARLIER METHODS}

Before any kind of windvane was developed or any kind of instrument was invented to measure the wind severity (Augustyn, et al. 1990), several craftsmen were dependent on the force of the wind. So life time experience told sailors when to sail and how mary sails could be hoisted (Ball, 1995). Similar experiences told millers when winds were favourable to grind on their mills, how many sails had to be used when the wind was calm and when the mill had to be stopped whenever thunderstorms approached. However, no satisfactory method was yet applied to measure the wind direction and severity. Consequently, no instrumental data are available from the period 1488 to 1609 (Geurts et al. 1983; Woudenberg, 1989; Demarée, 1990). That is why we are forced to look for another method to measure the impact of storms and gales during the period in question and the part they played in the history of climate as such.

Looking first at the method used by Easton (1928), it must be mentioned that he only used ten terms to qualify winter severity in historical times. I agree with Alexandre $(1980,1987)$ that more than one source is needed or a simple expression of weather phenomena alone to assess the impact of elimate. But I consider it to be an exaggeration to say Easton's method is quite useless.

Secondly, Gottschalk $(1971,1975,1977)$ has studied storm surges mentioned in numerous chronicles in the Low Countries till 1700 . She considered it to be possible to quantify weather data, if such a quantification is preceded by a very thorough research of all the available contemporary documentary sources. The only question that remains, is how such a quantification should take place and in particular how such weather data can be translated into an operational method in order to assess the impact of storns and storminess in historical climate during a particular period.

In this respect, Lamb (1991) went one major step forward. He designed a storm severity index for all major storms recorded around the British Isles starting at the beginning of the sixteenth century, In order to assess the severity of a storm he takes into consideration: (a) the greatest wind speeds indicated at the surface; (b) the greatest area covered by the storm; (c) the total duration of the occurrence of the damage; and, of course, (d) the damage itself done by the storm. Of the total number of 166 storms counted, the sixteenth century only includes 11 storms, the nineteenth century 35 and the twentieth century, which has not even ended yet, as many as 63 . Due to the closer coverage of weather, Lamb admits that the criteria in question apply best to the last two and a half centuries. So this means, that in times during which there was no instrumental measuring of windspeed, criteria (c) and (d) are the only ones left that enable us to construct a method to assess the impact of storms.

Does this mean that we should leave it there and be satisfied that we will never be able to assess storminess during the pre-instrumental period (Augustyn, 1992, 141143) ? No, I think it invites us to look for more and perhaps for other criteria. 
First, it invites us to make a reliable annual inventory of as many climatic daka as possible. After having made such an inventory, it is possible, of course, to count the number of high tides, storms and storm surges. Counting numbers only, gives us a picture of years with a large number of storms and years with a smaller number of storms. This method does not give us an understanding of, for example, the directions the storms blew from nor of any change in such a pattern, if there were one to be detected anyway. Moreover, ten breezes may seem more serious than 4 storm surges. Counting numbers only does not tell us anything about wind severity nor the direction of wind or wind patterns!

\subsection{PROPOSED NEW METHOD}

So, starting with the contemporary source material, a method must take into account the way in which the contemporary recorder describe the high tides, storms and storm surges in question. Does the description reveal something about the direction and the duration of the storm. Furthermore, the exact wording of a particular storm can be highly relevant. How many words does he use to describe the storm and what kind of words? It is important to know whether the chronicler himself has observed the storm or has learnt about it from others. And how much was he involved? The question of the reliability of the wording alone is quite a different matter (see below). A second highly important criterion deals with the consequences to which these events have led. How many acres were flooded, how many houses were destroyed and how many people were drowned? And thirdly, all kinds of additional evidence of whatever nature must be implied in assessing the impact of our data. In order to do so, each and every high tide, storm, storm surge and even every thunderstorm must be 'measured'. I propose to do this in eight categories on which I will elaborate further. Each category will be sustained with a few examples taken from the weather inventory, 1488 to 1609 (De Kraker, 1997).

Category 1. High tides that have not led to any real damage and have been mentioned only once in the sources are given 1 point. One such high tide occurred in 1497 in the area around the Braakman. Only slight damage was done, however, enough to be recorded. Another high tide occurred on 5 February 1566 and left its marks. Just enough to be recorded.

Category 2. High tides that coincide with storms and have led to considerable damage to the dikes. Very often these high tides are mentioned in more than one contemporary source. We have given these high tides 2 points. It should be noted, however, that it is important to know whether damage is done to a newly constructed dike or to a 'greent or old dike. Of course, the first dike is much more vulnerable to storm damage than the second. One such high tide occurred on Christmas Day in 1535 and caused considerable damage to a sluice. Another high tide occurred in November 1559 and caused a great deal of damage to the works that protected the 
dikes at Terneuzen.

Category 3. The kind of storms that result in damage to several places at the same time. Such storms often coincide with high tides as well and are called 'tempest and high tide'. Although these kinds of storms seldom have a general character and are characterised by a very wide range, we have given these storms 3 points. It should be noted these tempests can already lead to wind mills being blown down, if the storm changes into a thunderstorm. The year 1573 , in particular, was affected by several storms in a row. All of these storms did damage to the coastal defence.

Category 4. Severe storms that cause heary damage to several places at the same time. These types of gales have a more general character and have been given 4 points. These storms often lead to the blowing down of wind mills as well. One such severe storm affected the coast of the Braakman in 1494 and did cause a great deal of damage there at several places. Another severe storm (oraige de vent et tempeste de mer') dates from September 1539 and a third from December 1575. Both storms caused a great deal of damage at several places.

Category 5. Heary gales that lead to heavy damage to several places and even to the flooding of at least one polder. We have given these severe gales 5 points. It should be noted that it is important to know something about the condition of the dikes of the polder flooded. One such heavy gale occurred in 1516 and led to the flooding of the Willemskerckepolder and caused some additional damage at other places. Another example dates back from 1594.

Category 6. Heavy galewinds that lead to heavy and large-scale damage and flooding at several places. These types of gales generally coincide with northerly or south-westerly winds at spring tide. We have given this type of weather 6 points. Very often the duration of the storm is decisive. One such tempest occurred in 1609 and lasted for nearly two days on 17 and 18 February. A few polders were destroyed.

Category 7. Storm surge followed by general and large-scale flooding restricted to certain locations. These types of storm surges coincide with north-westerly or southwesterly winds that continue to blow for many hours or even 24 hours in a row at spring tide. So water is constantly accumulating in the estuary of the Wester Scheldt or along the shores of the North Sea. We have given this type of weather 7 points (see below).

Category 8. Storm surge followed by general and large-scale flooding in a wide coastal area. These types of storm surges continue to be active up to 24 or more hours at two or even three separate spring tides. In these circumstances waters hardly run back during low tide and are easily reaccumulated during the next high tide. We have given this type of weather 8 points (see below).

\subsection{TERMINOLOGY DECISIVE?}

Two cases show how important documentary sources are whenever only the terminology used is taken into consideration. The examples are taken from the documentary sources mentioning the storm surges of 1530 and 1570 that ravaged the 
region of the Vier Ambachten and the Land of Saeftinghe.

As for the inundation that took place on 5 November 1530, sources reveal rather different reports of the event. Some reports were full of emotion, especially during the

Table I

Terminology used to describe the storm surges of 1530 and 1570 in the Vier Ambachten and the Land of Saeftinghe

1530, 5 November Terminology applied

1. an inundation of the seas so large-scale as has never seen before

2. universal inundation

3. in The inconvenience caused by the large-scale and great inundation

4. The hazard tempest and tempest of the sea

5. ...tempest and thundering of the seas...

6. ...the tempest and high seas.../ the worst tempest and inundation of the seas

7. High floot

8. ... large inundation.... around two $a^{\prime}$ clock in the afternoon... a full moon... great tempest of wind and of a long duration

1570,2 November

9. Fourth inundation... large-scale damage unbelievable... never have seen such an inundation before and never heard of such damage before

10. Great tempest..

11. Flooding of the sea and water...

12. Inundation and tempest of the sea

13. Inndation and large flood

14. $\ldots$ a general and horrible inundation...

15. ...large flooding and breaches caused by the sea

16. Great violence of the notherlies and high flooding of the sea..

17. Pitiful inundation
Sources

Letter 8 November, Jan, Lord of Bergen to the governess in Brussels.

9 November, receiver of Zealand. Receiver-general of Flanders.

Letter 17 November, Filip Nigri, master of requests to the Secret Council.

27 November, Jean de Luxembourg, governor of Flanders.

May-June, several officers at the Brassels court.

November 1530-1531, several officers.

1530-1531, Abbey of St. Peters at Ghent. 1530-1531, Abbcy of Terhagen near Axel.

3 November, Ghent chronicler.

8 November, government decree.

3 December, government decree.

8 December, receiver-general of Flanders.

1570.1571 , receiver of the Chapter of O.L. at Kortrijk.

n.d., Abbey of Terhagen near Axel

n.d., receiver of the Chapter of O.L. at Kortrijk.

2 November, eyewitness at Sas of Ghent.

December 1571 , large estate-owners at Zaamslag.

All dates mentioned here are Old Style, cf. note 1. 
first few weeks. But then sources began to apply standard expressions, such as tempest and inundation. A few sources, however, elaborate on the disaster and mention the circumstances under which the flooding took place (see below).

The sources that elaborate on the 1570 storm surge paint a disturbing picture as well, because expressions such as 'horrible', 'awful' and even 'pitiful' were used on several occasions. Remarkably enough the Brussels administration worked very hard to avoid such standard expressions.

It is a common fact that contemporary sources tend to exaggerate natural disasters. Storm surges especially are described as a phenomenon 'never seen before during man's life'. In other words contemporary sources tend to consider storm surges to be unique. Looking more closely at our two natural disasters we find that the expressions used to describe the storm surge in 1530 and the one in 1570 range from simply 'bad weather' to 'storm surge'. Moreover, the latter storm surge was expressed in a more emotional way than the first one. Do our two examples imply that the storm surge of 1530 was more destructive than the one in 1570 ? Strangely enough, it appears that whenever more documentary sources are available for one major storm surge, the more difficult it becomes to assess its true nature. This is apparent if we only take into consideration the wording used in the documentary source.

However, our sources are uniform and continuous and more major storm surges are mentioned, e.g. September 1509, December 1511, November 1530, November 1532, January 1552, February 1552, November 1570 and April 1606 . Analysing all of these major storm surges by close comparison is already a major step closer to the assessment of the true nature of each storm surge. So it is important to know the purpose for which contemporary recorders wrote down their findings and experiences. A receiver mentioning the flooding of a polder due to inadequate upkeep of the dikes choose his words in a more careful way to explain the disaster, than the chronicler 'just passing by'. However, the problem of contemporary sources minimising or maximising the nature of the disaster can be dealt with in a simple way. In this respect the expressions used can be useful, but should not be decisive. The same applies to the assessment of the high tides and lesser storms.

However, constructing a method to assess the impact of storms by exclusively applying the expressions used in the documentary sources, provides us with a basis which is too small. That is why it is necessary to look for other criteria as well.

\subsection{OTHER FACTORS INCLUDED}

In order to rale out every doubtful element in the way the documentary source expresses climatic data about high tides, storms and storm surges, we must include a second basic principle. We should take into consideration the consequences to which a storm surge has led. One major consequence can easily be measured, for example, the number of acres flooded (Table II).

All kinds of damage done to the dikes, mills, etc. can be measured as well. 
However, the real impact of that damage can only be assessed, if our documentary sources are analysed very carefully. Of course, it makes a difference if a newly constructed dike has been damaged instead of an old one and, of course an old (decayed) windmill will tend to be blown down much sooner during a thunderstorm than a newly constructed one. Such differences can only be ruled out whenever sources are uniform and continuous.

Finally our documentary sources occasionally mention something about the direction of the storm and something about its duration. So apart from the wording and the consequences to which a storm has led, all auxiliary evidence must be taken into consideration.

Table II

Number of acres flooded by the major storm surges, 1509-1606 in the Vier Ambachten and the Land of Saeftinghe

\begin{tabular}{llr}
\hline Storn surge & \multicolumn{2}{l}{ Number of acres flooded } \\
\hline 1509 & approx. & 3,124 \\
1511 & approx. & 4,092 \\
1530 & approx. & 14,740 \\
1532 & approx. & 5,368 \\
1552 & approx. & 5,456 \\
1570 & approx & 10,868 \\
1606 & approx. & 1,461 \\
\hline
\end{tabular}

All stom-winds concemed are north-westerlies, westerlies, south-westerlies and in some cases even north-easterlies. North-westerlies, however, tend to cause most serious damage in the region concerned. So, in December 1492 a north-westerly flooded a small polder near Axel (De Kraker, 1997, table 11.1). Most north-westerlies and westerlies tend to amass water in the Wester Scheldt estuary. In March 1590 a continuous north-easterly did cause damage in some coastal areas north of Hulst. Most north-easterlies tend to pile up ice on the dikes when a thaw sets in at the end of severe frost. A chronicler writing about the storm surge that occurred in November 1530 records the direction and duration of the wind most elaborately. The high tide on 5 November 1530 was accompanied by a vehement tempest on Thursday, carrying on the next two days. On Saturday the moon was full and the tempest then even gained momentum. In consequence, the seas rose far above the land beginning at Middelburg as far as beyond Antwerp. The seas ran over the dikes as high as a Hamburger beerton ( 2.5 feet) and many cattle were drowned. So at Antwerp the spring tide reached one foot higher than had been the case in 1509 and 1511.'(2)

Another chronicler reports on the storm surge that occurred on 13 January 1552. The wind gained momentum at $9 \mathrm{o}^{\prime}$ clock on the eve of the disaster lasting through the afternoon on the next day (De Kraker, 1997, p. 182). Some Antwerp chroniclers even speak in terms of the fourth storm surge and a fifth pointing to the storm surge that 
occurred one month later in 1552 (3). Some sources reveal something about the height to which waters rose during a storm surge. Some sources even give comparisons between heights reached at present storm surges and former ones.

In order to assess the impact of high tides, storms and storm surges as vital elements of climatic history, the examples cited show that our three principles enable us to measure the impact of storm data in more than just an approximate way. This finally leads us to say something more about the documentary sources (De Kraker, 1997).

\section{The documentary sources}

The landscape of the northem part of the ancient county of Flanders is characterised by polders and dikes. The polders were created by man along the shores of the Wester Scheldt, being the main estuary in this region. As the soil in most of these polders was very fertile, they generally produced abundant crops. So the upkeep of the dikes that surrounded the polders was vital for the survival of its inhabitants and, in case of flooding, repairs were carried out very quickly.

The upkeep and repair of dikes and waterways was entrusted to special officers, called sheriffs. These sheriffs were assisted by a board of aldermen, a measurer and a receiver.

Each polder had its own board and because there were matry polders, there werc many such boards as well. Only when a large property holder owned two or more polders were larger boards created. In consequence, the count of Flanders owned a few polders situated and concentrated along the Wester Scheldt, as did some important Flemish monasteries. In such cases the count or the monastery appointed the members of the boards and the officers in question.

The actual annual upkeep of the dikes was carried out twice, once in spring and the second during autumn or winter (De Kraker, 1997). In between, each dike was inspected regularly, especially when storms and gales affected the area and had caused damage to the dikes. Each case of damage led to extra money being spent. In order to be acquitted, the receiver had to answer very carefully for each additional spending. And whenever severe gales led to breaches in the dikes and flooding of the land, a thorough inspection was carried out. So, apart from many additional notes in his account and the receipts, reports have very often been preserved of the damage caused to the dikes and the kind of weather conditions that led to the damage. This results in the administration of the receiver of the dikes to be of great interest for climatic research, for example, the frequency and severity of storms and gales.

Fortunately, a few series of dike accounts have been preserved that are continuous and fairly uniform. Most important are the accounts of the dikes situated in the domain of the count of Flanders along the shores of the Wester Scheldt. This domain is called 'The Polder van Namen \& Triniteyt'. The series of dike accounts nuns from 1487 to 1612 (4). A second important series of accounts of the so-called Landdijk of the Vier Ambachten' covers the period from 1509 to 1566 (5). The reasons for 


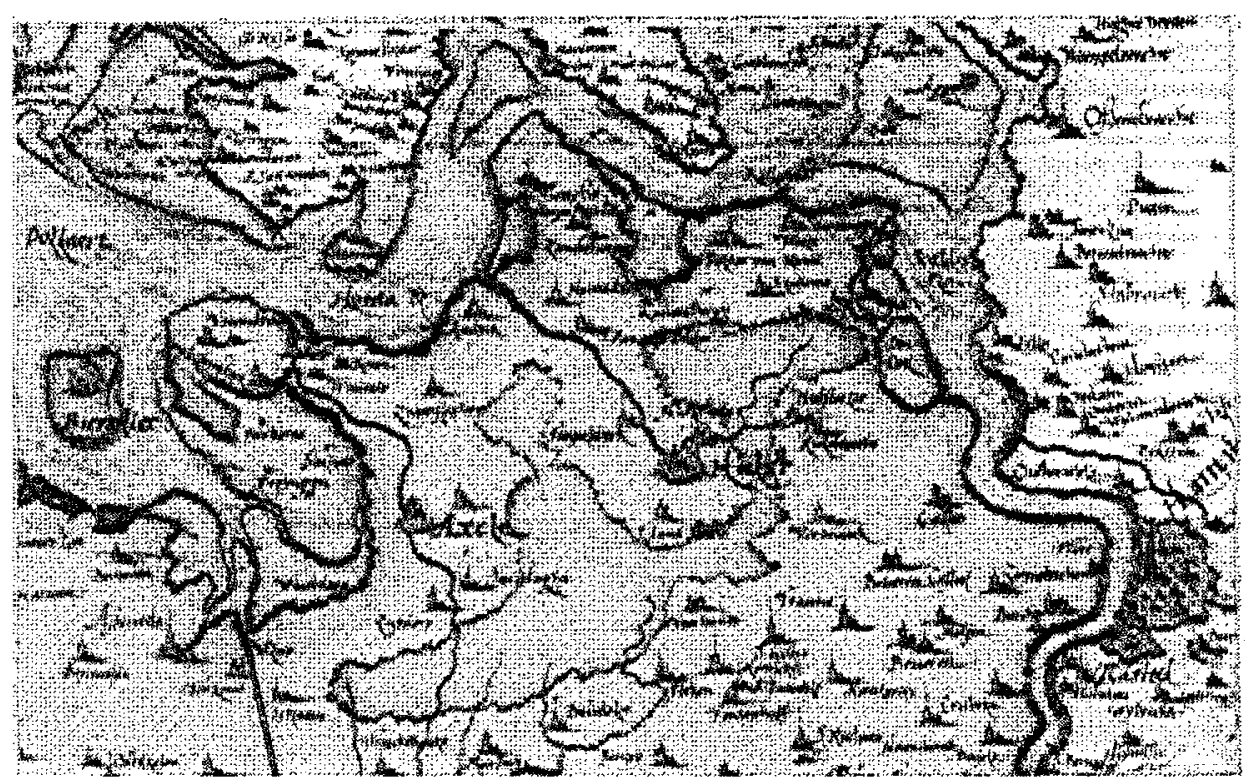

Figure 2. The coastal region of the Vier Ambachten and the Land of Saeftinghe in the sixteenth century (Copyright Royal Library Albert I, Brussels, Belgium, Clristian 'sGrooten map, detail).

expenses made on behalf of the upkeep of various other dikes have been explained in a number of different accounts of domains of monasteries. Furthermore, special and rather detailed information is available about anomalies as well (Pfister et al. 1994).

A special number of dike accounts is preserved each year when floodings took place. A number of storm surges (see above) affected the polder region (Brandon, 1971; Pavese et al. 1994; De Kraker, 1997). All these special dike accounts give details of the kind of storm surge that struck the region and broke the dikes (6).

Finally, a large amount of correspondence is available about the whereabouts of the dikes (7). And many a chronicler took the trouble to record in his diary what he learnt from his contemporaries (8). Some even witnessed one or two natural disasters themselves.

Considering all the documentary sources mentioned above, there is, of course, a danger. For the second half of the sixteenth century a larger quantity of sources is available which might tend to increase the apparent number of storms (Lamb, 1991, pp. 6 and 9). However, most of our series of dike accounts end about the last quarter of the sixteenth century, so there are several series which continue to be uniform and homogeneous throughout the first three quarters of the sixteenth century. On the other hand, large piles of letters dating from 1580 to 1585 do not provide us with more storms. However, as early as $\mathbf{1 5 8 5}$ an increase in the amount of correspondence must be held slightly responsible for the increase in storminess. 


\section{Analysis and calibration}

It is clear that the documentary sources in question contain a considerable amount of climatic data relating to stominess. It can already be very rewarding to count the number of high tides storms and storm surges mentioned. This enables us to determine the rise and decline in numbers from 1488 to 1609 . It also enables us to distinguish periods of greater storminess and periods of lesser storminess.

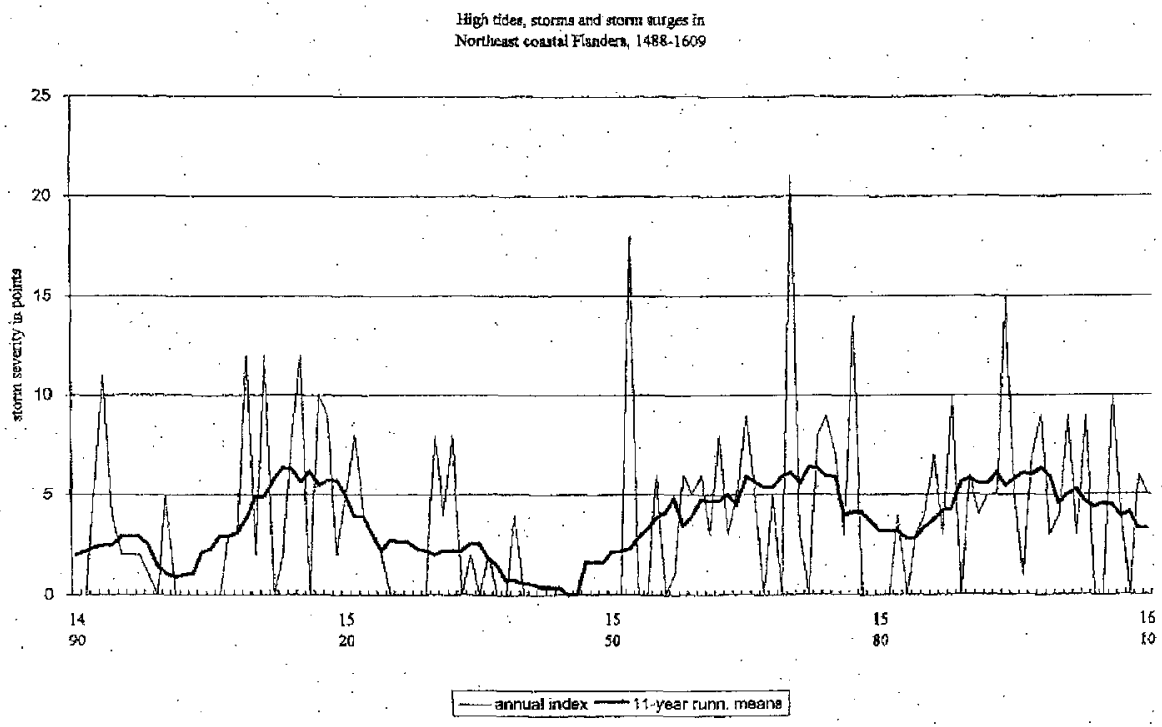

Figure 3. High tides, storms and storm surges in north-east coastal Flanders, 1488 - 1609. 'Storm severity in points' is indicated on the left. Thin line indicates the 'annual indice'. The fat line indicates the 'eleven-year running average'.

As pointed out above, counting numbers only does not give us an understanding of the true nature of the more and less stormy periods. Therefore we have categorised the climatic data according to the principles discussed earlier. The annual results and a continuing eleven-year-average are shown in Figure 3. From this a rough and rather unstable pattern emerges, showing periods with a greater storm frequency (1509$1520,1550-1575$ and 1590-1606) and periods with a lesser storm frequency. If we were to compare the frist half of the period (1490-1549) with the second half (15501609), it appears that there is an increase in storm activity of about $85 \%$.

On the whole, this pattern rules out the suggestion that the availability of more written sources for the second half of the period is responsible for the remarkable increase in storminess (see above). Accordingly, there is definitely a large increase in storm frequency during the second half of the sixteenth century. To explain this increase, however, it is necessary to analyse our categories more closely, which is 
shown in Table III.

Table III

Analysis of the frequency of high tides, storms and stom surges, $1490-1615$

\begin{tabular}{lcccc}
\hline Period & Cat. 1-2 & cat 3-4 & cat 5-8 & Total \\
\hline $1490-1549$ & 29 & 14 & 9 & 52 \\
$1550-1615$ & 23 & 59 & 12 & 94 \\
\hline
\end{tabular}

From our closer analysis it appears that, in particular, the number of lesser storms (cat. 3-4) has in fact increased fourfold. So the number of storms that caused serious damage to the dikes and polders has increased dramatically during the second half of the sixteenth century. Even the number of storms and storm surges that caused severe damage to the dikes and even flooded land increased throughout the second period.

To put our results in a much broader perspective the following questions may be asked. Why did stormy weather appear more frequently throughout the sixteenth century? Was there any dominant direction from which the winds blew from and, if so, did that direction change during the period? Unfortunately, our sources rarely mention such circumstances. Only in the case of a storm surge (cat. 7 and 8) is information given about the kind of winds that were blowing. One such example is the storm surge of 1530 , mentioned earlier.

However, one thing is beyond any doubt, high tides, storms and storm surges could cause damage to the dikes and flooded polders only if they coincided with northwesterly and south-westerly winds. So our increase in storm frequency is in fact an increase in such winds throughout the second half of the sixteenth century.

This leads us to the important question, whether periods of an increased storminess are just isolated features and quite accidental, or are there still more periods showing a similar pattern of storminess? In order to answer this question, we will have a look at the period between 1848 and 1990 .

For over one and a half century 'Rijkswaterstaat', the Dutch national institute guarding the dike system keeps a record of storm surges. One such record has been kept for Flushing. This town is situated at the mouth of the Wester Scheldt, a little to the west of the region of de Vier Ambachten and Saeftinghe, so the uniformity in place can be respected. The Flushing record of storm surges contains the date and duration of the storm surge and the maximum level of each high tide the storm surge reached. When water level surpasses the level of high tide, it is called spring tide. Whereas the impact of storm surges has hardly been studied for this recent period, we depend on the instrumental measurements only. So, in order to assess the impact of storminess, we have not only counted the annual number of storm surges, but also the amual number of high tides during which storm surges appeared. Having the most 
THE CASE OF STORMY WEATHER AND DIKES IN THE NORTHERN PART OF FLANDERS 299

destructive impact on landscapes and human society, the number of spring tides and the level that spring tides reached during storm surges seem to be the most crucial data to assess storminess.

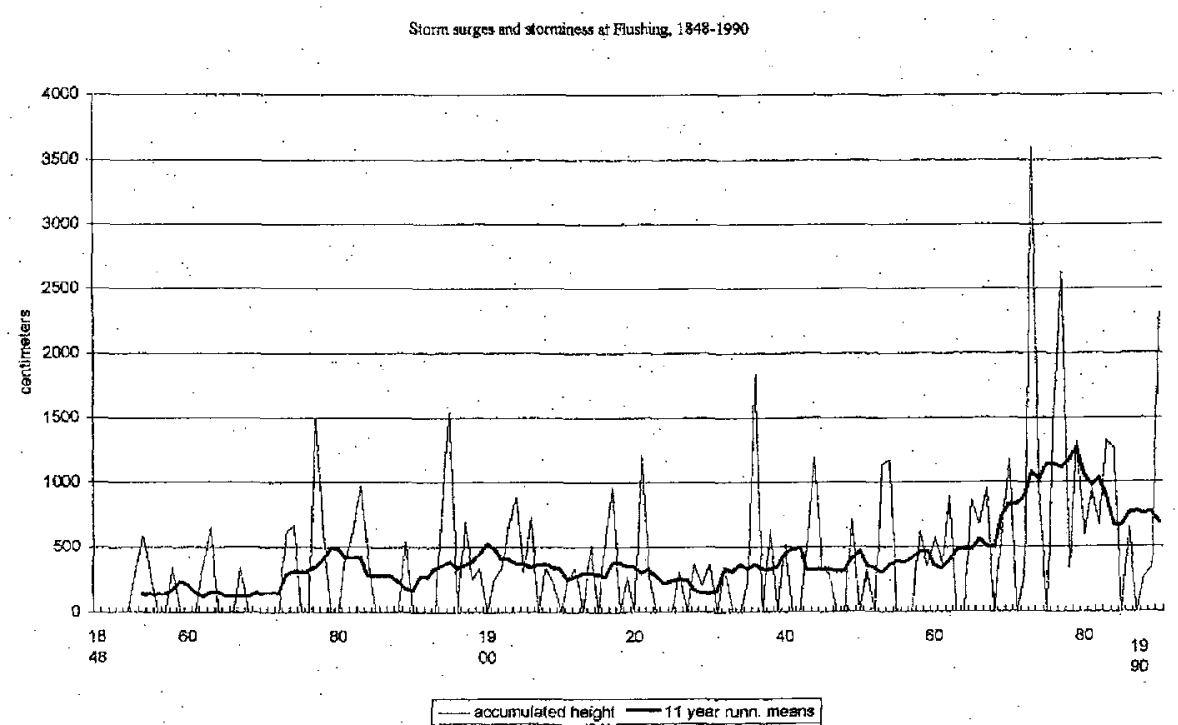

Figure 4. Storm surges and storminess at Flushing, 1848-1990.

Figure 4. shows a remarkable increase in storminess starting around the 1950s (Ministerie van Verkeer en Waterstaat, 1994; Lamb, 1991). This increase is due to a higher number of storm surges and consequently to a higher number of spring tides during which there was a storm surge. In 1973, e.g., there were seven days with a storm surge, covering a total number of eleven spring tides.

Of course, the continuous process of sea level rising between 1848 and 1990 should be taken into consideration as well. During this period the general rise in sea level at Flushing is about $0.30 \mathrm{~m}$ (Van Malde, 1996). Between 1875 and 1990 the level of high tide at Flushing increased by half a meter, while the level of spring tide increased by slightly more than half a meter. Starting around 1886, the process of sea level rising, however, was a very gradual process, whereas the increase in storminess during the last half a century has been relatively strong. As far as the period 1964 to 1990 is concemed (Augustyn et. al. 1990) and storms grading Beaufort force 8 and over, the predominant direction of the wind seems to be south to south-west.

There is a fair degree of similarity between the increase of storminess during the second half of the present century and the second half of the sixteenth century. Now the second half of the sixteenth century is known for its cooling off. The second half of our present century seems to be one of a spectacular warming up. In both cases the relatively strong increase of storminess seems to be preceding climatic change. 
Whether this is the real cause of climatic change or just one of them, it should, however, urge us to continue our research in this respect.

\section{Concluding remarks}

In this paper research has been carried out into Flemish documentary sources from the sixteenth century that provide us with special data of local climatic history relating to high tides, storms and storm surges. Analysis of these data has made it possible to develop a method that can help us to assess the impact of these weather phenomena between 1488 and 1609 . This method is based on three main principles. The method not only considers the kinds of expressions used by contemporaries to account for a storm or storm surges, but also takes into consideration the conditions in which a storm occurred and the consequences to which it led. The data enable us to compare the weather anomalies, for example, storms, and accordingly we can categorise these climatic data. Our method has led to the emergence of an interesting storm pattern during the sixteenth century. From this storm pattern important changes can be derived, such as a rise of about $85 \%$ in storm frequency during the second half of the sixteenth century in the northern part of Flanders and the province of Zealand along the Wester Scheldt. Indeed, it appears that the area with storminess has moved more toward the Wester Scheldt estuary during the sixteenth century (Lamb, 1980).

In spite of all scepticism that such a method can never be scientifically applied at all (Augustyn, 1992), I agree that everything possible should be done. However, realizing that we are dealing with a pre-instrumental but highly richly documented climatic period, how critical should one be? I, for one, cannot continue to accept no for an answer.

Therefore, I am convinced that it could be very rewarding to carry out a broader study into high tides, storm and storm surges along the North Sea coast based on this method and accordingly obtain a deeper understanding of the impact of climatic history during the sixteenth century.

Finally, looking at the results of our proposed new method of measuring the impact of storminess in historic times and comparing these with a more recent period shows that there is a similar strong increase in storminess beginning around the 1950s. Whereas the relatively strong increase in storminess during the second balf of the sixteenth century coincided with the cooling off of our climate, a similar increase in storminess during the second half of our century coincides with the warming up of our climate. Could it be that relatively strong changes in storminess precede climatic change? If this were the case, our further research should focus on climate data from documentary sources from historic periods during which dramatic climatic change seems to have occurred. 
THE CASE OF STORMY WEATHER AND DIKES IN THE NORTHERN PART OF FLANDERS 301

\section{Acknowledgements}

I would like to thank Prof. Dr. G.J. Borger (University of Amsterdam, Netherlands); Dr. John Kington (University of East Anglia, Norwich, England); Prof. Dr. Chr. Pfister (University of Bern, Switzerland); Prof. Dr. R. Brázdil (University of Bmo, Czech Republic); Dr. H. von Storch (Institute of Hydrophysics, Germany) and John de Ronde (Rijksinstituut voor Kust en Zee, the Hague, Netherlands) for their assistance and advice.

\section{Notes}

1. In the Catholic Low Countries, the New Style was introduced in December 1582. Strubbe and Voet, 1960, pp. 46-49. All dates earlier than 14 December 1582 should be corrected by +10 days for the provinces of Zeeland and Brabant; for the county of Flanders this correction applied prior to 20 December 1582. In this paper corrections bave been made only in Figure 3

2. Royal Library Albert I at Brussels, ms. II-1593.

3. Ibid, ms. 17.243.

4. Archives Gétérales du Royaume at Brussels (AGR), Chambre des Comptes (CdC), nr. 27934-28033, covering the period 1487 to 1612 .

5. AGR CdC, mr. 27801-28811 covering years 1493 to 1510 ; nr. 27865-27912, covering the years 1510 to 1566 .

6. AGR CdC, nr. 27810-27820, 27891, 28044-28050; 28053 and 28058 (floodings in 1509, 15111530 and 1532); nr. 28054 (flooding in 1552) and nr. 28051 (flooding in 1570).

7. Correspondence covering the flooding years with all kinds of government councils and officials, preserved at the Archives Générales du Royaume at Brussels (Audience, Chambre des Comptes ...). Correspondence with the local governments and councils of justice at Ghent (Council of Flanders, preserved at the General Archives at Ghent). Correspondence with the numerous monasteries possessing land in the affected area.

8. University Library at Ghent, ms. 159.

\section{References}

Alexandre, P.: 1980, Les variations climatiques en Belgique et en Rhénanie d'aprẻs les sources écrites de la période 1100-1600', in Verhulst, A en Gottschalk, M.K.E., Transgressies en occupatiegeschiedenis in de kustgebieden van Nederland en België, Gent, pp. 243-251.

Alexandre, P.: 1987, Le climat en Europe, Paris.

Augustyn, B., Daan, H., Van Mourik, B., Messerschmidt D and Zwart, B: 1990, Stormkalender 1964 - 1990. Royal Dutch Meteorological Institute, De Bilt, nr. 176.

Augustyn, B:: 1992, Zeespiegelrijzing, transgressiefasen en stormvloeden in maritiem Vlaanderen tot het einde van de XVIde eetw. Een larkischappelijke, ecologische en klimatologi sche studie in historisch perspektief, Brussel, 2 vol.

Ball, T.F.: 1995, Historical and instrumental evidence of climate: western Hudson Bay, 
Canada, 1714-1850', in Bradley, R.S. and Jones, P.D., Climate since A.D. 1500, London and New York, pp. 40-74.

Bradley, RS.: 1994, Reconstruction of Climate form A.D. 1000 to the Present', in Brázdil, R. and Kolar, M., Contemporary Climatology, Bno, pp. 12-22.

Brandon, P.F.: 1971, Agriculture and the effects of floods and weather at Barnhorne, Sussex, during the Late Middle Ages, Sussex Archeaological Collections, vol. CIX

Demaree, G.R: 1990, 'On the re-discovery of the XVIII-th century daily meteorological observations carried out at Verviers by G.L. Godart', in Bulletin de la Société Belge d'Etudes Géographiques - SOBEG, 2, pp. 171-180.

Easton, E.: 1928, Les hivers dans l'Europe occidentale, Leiden.

Geurts, H.AM. and Van Engelen, A.F.V.: 1983, Geschiedenis van weerkundige waarnemingen in het bijzonder in Nederland voor de oprichting van het K.N.M.I., De Bilt, nr. 165-I.

Gottschalk, M.K.E.: 1971, 1975 and 1977, Stormwloeden en rivieroverstromingen in Nederland, Assen, 3 vols.

Ingram. M.J., Underhill, D.J. and Farmer, G.: 1985, 'The use of documentary sources for the study of past climates', in Wigley, T.M.L., Ingram, M.J. and Farmer, G., 1985, Climate and History. Studies in past climates and their impact on Man, Cambridge UP, pp. 162-180.

De Kraker, A.M.J.: 1997, Landschap uit Balans. De invloed van de natuur, de economie en de politiek op de ontwikkeling van het londschap van de Vier Ambachten en het Land van Saeftinghe tussen 1488 en 1609 , Utrecht.

Lamb, H.H: 1980, 'Climatic fluctuations in historical times and their connection with transgressions of the sea, storm floods and other coastal changes', in Verhulst, A. and Gottschalk, M.KE., Transgressies en occupatiegeschiedenis in de kustgebieden van Nederland en België, Gent, pp. 251-285.

Lamb, H.H. 1991, Historic Storms of the North Sea, British Isles and Northwest Europe, Cambridge UP.

Malde, J. van: 1996, 'Fistorical extraordinary water movements in the North Sea area', Mededelingen Rijks Geologische Dienst, nr. 57, pp. 27-39.

Ministerie van Verkeer en Waterstaat: 1994, Tienjarig overzicht, 1981-1990, Rijkinstituut voot Kust en Zee The Hague.

Pavese, M.P., Banzon, V., Colacino, M., Gregori, G.P. and Pasqua, M : 1995, 'Three historical data series on floods and anomalous climatic events in Italy', in Bradley, RS. and Yones, P.D., Climate since A.D. 1500, London and New York, pp. 155-170

Pfister, Chr., Kington, J., Kleinvogel, G., Schüle, H. and Siffert, E., 1994, 'High resolution patio-temporal reconstructions of past climate from direct meteorological observations and roxy data', in Frenzel, B., Pfister, Chr. and Gläser, B., Climatic trends and anomalies in Europe 1675-1715, Stuttgart/Jena/New York, pp. 329-377.

Strubbe, Eg.I and Voet, L: 1960, De chronologie van de Middeleerwen en de Modeme Tijden in de Nederlanden, Antwerp/Amsterdam.

Woudenberg, J.P.M.: 1989, Geschiedenis van de larkbonwmeteorologie in Nederland tot 1972. Technical Reports nr. 116 of the 'Royal Dutch Meteorological Institute', De Bilt. 